\title{
Recombinant herpesviruses as tools for the study of herpesvirus biology
}

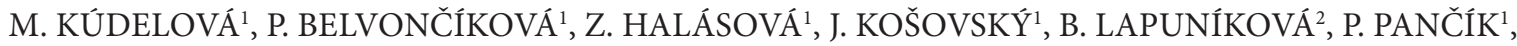 \\ I. REŽUCHOVÁ ${ }^{1}$, M. ŠUPOLÍKOVÁ², V. ZELNÍK ${ }^{1}$
}

\begin{abstract}
${ }^{1}$ Institute of Virology, Slovak Academy of Sciences, Dúbravská cesta 9, 84505 Bratislava, Slovak Republic; ${ }^{2}$ Comenius University, Faculty of Natural Sciences, Bratislava, Slovak Republic
\end{abstract}

\begin{abstract}
Summary. - This article is a brief summary of efforts to generate mutant herpesviruses for investigating and assigning gene functions of herpesviruses in replication and pathogenesis. While a full review of all herpesviruses is beyond the scope of this review, we focused our attention on the prototype of the herpesvirus subfamily - herpes simplex virus and murine gammaherpesvirus that serves as an excellent animal model to study human gammaherpesvirus pathogenesis. Furthermore, our present knowledge of essential, non-essential, and common genes of herpesviruses as well as of accessory genes that are currently being studied with the help of the bacterial artificial chromosome (BAC) system will also be discussed. This system facilitates the analysis of herpesviral genes with potential for use in gene therapy or as anti-cancer therapeutics.
\end{abstract}

Keywords: herpes simplex virus; murine gammaherpesvirus; bacterial artificial chromosome system; recombinant herpesvirus; herpesviral gene function

\section{Contents:}

1. Introduction

2. Conservation of genes and protein function in herpesviruses

3. Deletion mutagenesis as a tool to assign gene function of herpesviruses

4. Elucidating herpesvirus biology with the help of studying HSV-1 mutants

5. Studies on gene functions via application BAC system to herpevirus genomes

6. Elucidating gammaherpesvirus biology with the help of studying mutants of murine gammaherpesvirus

7. Conclusion

Email: virukude@savba.sk; phone: +4212-59302434.

Abbreviations: $\mathrm{BAC}=$ bacterial artificial chromosome; $\mathrm{EBV}=\mathrm{Ep}-$ stein-Barr virus; FGARAT $=N$-formylglycinamide ribotide amidotransferase; HCMV = human cytomegalovirus; HHV-1-8 = human herpesviruses 1-8; HHV-6,7 = human herpesviruses 6 and 7; HSV-1,2 = herpes simplex virus 1 and 2; IRF-7 = IFN regulatory factor 7; KSHV = Kaposi's sarcoma-associated herpesvirus; MHV-68 = murine gammaherpesvirus $68 ; \mathrm{VZV}=$ varicella-zoster virus

\section{Introduction}

To date, the family of herpesviruses comprises important human and many veterinary relevant pathogens encompassing more than 100 herpesviruses that infect vertebrates. A common feature of herpesviruses is their ability to infect the host for life. Classification of herpesviruses and separation from other virus families was initially done on the basis of biological properties such as the propensity for latency in a certain cell type and the clinical manifestation of the virus. Later on, virion structure, cell tropism, virus host range, high complexity, and more recently, genome sequence data were taken into account as another important feature by which herpesviruses stand out from other virus families. Viruses of the family Herpesviridae have been classified into three subfamilies, Alphaherpesvirinae, Betaherpesvirinae, and Gammaherpesvirinae. The alpha subfamily is estimated to have diverged from the beta and gamma subfamilies 200-220 million years ago (Roizman and Baines, 1991; Fu et al., 2008).

Regardless of subfamily, herpesvirus virions have similar ultrastructural morphology, which comprises an envelope, a capsid with icosahedral symmetry and a centrally located core with linear double-stranded DNA genomes ranging in length from 125 to $240 \mathrm{kbp}$. As there is currently more 
sequence data on herpesviruses, comparison of the genomes enables the identification of core genes that are shared within subfamilies, and unique genes that resemble adaptation to fulfil host specific prerequisites. Eight human herpesviruses belong to all three subfamilies of herpesviruses: alphaherpesviruses - herpes simplex 1 and 2 (HSV-1, HSV-2), varicella-zoster virus (VZV), betaherpesviruses - human cytomegalovirus (HCMV), human herpesviruses 6 and 7 (HHV-6, HHV-7), gammaherpesviruses - Epstein-Barr virus (EBV) and Kaposi's sarcoma-associated herpesvirus $(\mathrm{KSHV}))$. Although the complete DNA sequence of each of the human herpesviruses has been elucidated, there remains much to be learned about the function of specific viral gene products. Furthermore, since most human herpesviruses are very species-specific, insights into viral mechanisms of pathogenesis must rely on the study of other related vertebrate herpesviruses, about which even less is known at the molecular level. Although human herpesviruses vary at primary sites of replication and clinical manifestations of infection, they share many molecular similarities. Besides well-known data about diseases of which causative agents are herpesviruses, more recent findings suggest that infection with some herpes viruses (HSV-1, HHV-6, EBV, and VZV) is a significant aetiological factor of some neurological diseases (Hemling et al., 2003; Mancuso et al., 2007; Wozniak et al., 2009).

Since most human herpesviruses are very species-specific, insight into viral mechanisms of pathogenesis must rely on the study of other related vertebrate herpesviruses, about which even less is known at the molecular level. Due to recent advances in new sequencing technology, 49 herpesviruses genomes have been completely sequenced to date and stored in GenBank database (http://www.ncbi.nlm.nih.gov/ genomes) allowing for prediction of functions to genes via homology screening using computational biology methods as are sequence alignments, motif searches, and structure modelling. It is obvious that genome sequence comparison among herpesviruses will become even more significant in the coming years. Furthermore, more and more information about the hosts of herpesviruses available in the database may contribute to better understanding of how some genes might have been acquired by horizontal gene transfer, to abuse the host machinery for viral purposes (Holzerlandt et al., 2002). Comparison of conserved genes of different herpesviruses can help to identify important regions and motifs, as done e.g. for pUL89 of HCMV (Champier et al., 2007). Several programs allow for the search for patterns and motifs that can give valuable hints as to which process a gene is involved in or reveal functionally relevant sequences of a protein (Böttcher et al., 2006). To date, there are several genes with no clear homology to viral ones and their bioinformatic analysis will not provide any information about a putative biological role.

\section{Conservation of genes and protein function in herpesviruses}

The number of protein coding genes, also according to their genome size, varies between the subfamilies whereby Alphaherpesvirinae and Gammaherpesvirinae have on average around 70-80 genes and Betaherpesvirinae around 160-230 genes (Fu et al., 2008). There is a set of 43 highly conserved termed the 'core genes', commonly found in all herpesviruses, and that are mainly involved in the basic and fundamental procedures of the viral life cycle. Their products include capsid proteins, DNA replication proteins, DNA packaging/cleavage proteins, envelope glycoproteins, as well as several others involved in virus entry into the cell, viral DNA replication and packaging of the genome and maturation of infectious particles (Davison, 2002). Although herpesviruses are extensively studied there are still genes on the list of core genes, the functions of which are unknown (McGeoch et al., 2006)

Additional species and subfamily specific genes cover areas of cellular tropism, host shut-off or anti-apoptotic processes, evasion from the immune system and maintenance of latency (Alcami and Koszinowski, 2000; Mori and Nishizama, 2005; Andoniou and Degli-Esposti, 2006; Matis and Kúdelová, 2001, 2005). It is very likely that most of the remaining genes of unknown function will belong to one of these groups. Not all of these genes are necessary for viral replication in the host, but shape the outcome of the infection (Dunn et al., 2003).

\section{Deletion mutagenesis as a tool to assign gene function of herpesviruses}

To identify a function and role of specific wild type viral gene in replication and pathogenesis, the deletion or mutation of this gene as well as biological and biochemical assays of protein encoded is best elucidated by the generation of viral mutants studying their respective phenotypes while also computationally aligning them to homologue genes of known function. Specific viral sequences are subjected to mutagenesis, and following generation of recombinant viruses, the effect of the mutation(s) on the phenotype of the mutant virus may be assessed. This description of the virus has included quantifying gene expression in cell culture and also capability to replicate in a suitable animal model and to cause disease. Even though such studies have been laborious and technically difficult, a large number of mainly deletion mutants of herpesviruses with point mutations in individual genes or larger deletions in the genome prepared have provided an opportunity to describe the role of genes in growth and virulence. 


\section{Elucidating herpesvirus biology with the help of studying HSV-1 mutants}

HSV-1, discovered most likely first among the human herpesviruses, has been most intensively studied and is one of the most frequent and successful human pathogens. It grows rapidly in most types of cultured cells and can be handled more easily than other human herpesviruses. HSV-1 and HSV-2 cause a variety of diseases. Acute gingivostomatitis is the most common clinical manifestation of primary infection with HSV-1 in children, although the majority of infected individuals develop only trivial symptoms or remain asymptomatic (Simmons, 2002). Ocular and genital HSV infections are less common but are important in terms of the quality of life due to regular recurrence of virus reactivation. Recurrence in immunocompromised hosts however tends to be serious. Recurrent ocular herpes is the leading cause of corneal blindness, and genital herpes is one of the most common sexually transmitted diseases in industrialized countries (Liesegang, 2001; Corey, 2002). The virus is also the causative agent of life-threatening diseases such as herpes encephalitis and neonatal herpes (Kúdelová and Rajčáni, 2013). The prognosis of these serious illnesses has improved due to the introduction of anti-herpesviral drugs, but mortality from disseminated infection and central nervous infection is still high (Simmons, 2002). Because of their clinical importance as infectious agents and the intriguing biological properties of HSV-1 and HSV-2, there is continuing interest in understanding their pathogenesis.

The complete genomic DNA sequence of HSV-1 was published in 1988 and enabled the prediction of a total of 70 distinct open reading frames (ORFs) (McGeoch et al., 1988).

To date, HSV-1 belongs to the best-characterized herpesvirus, of which the genes including their functions in vitro and in vivo are nearly fully described. Although approximately half of the HSV-1 genes are not essential for replication in cell cultures, all accessory gene products are thought to play indispensable roles in viral replication and dissemination in vivo. Intensive studies have been undertaken to elucidate the functions and roles of an extensive and unique repertoire of gene products of HSV-1 involved in the regulation of gene expression, viral DNA replication, interaction with the host cell and immune evasion from the host immune system (Nishiyama, 1996; Dolan et al., 1998; Roizman and Sears, 1996).

The majority of HSV-1 protein's functions have been determined by analyses of viral mutants. Chemical mutagens were used for the first generation of recombinant herpesviruses to create temperature sensitive mutants more than 30 years ago (Schaffer, 1975). However, these temperature sensitive mutants usually had single or multiple mutations throughout the genome site, which made it difficult to map accurately and elucidate the function of specific viral gene products. More specialized techniques were then used to introduce site-specific mutations to the TK gene allowing its use as a positive selectable marker to generate mutant HSV-1 and HSV-2 isolates (Post and Roizman, 1981). Building on this approach, a similar "positive selection" marker strategy was adapted for the generation of cytomegalovirus mutants, using the guanosyl phosphoribosyltransferase gene (Mocarski and Kemble, 1996). Studies on temperature-sensitive mutants by random screening aimed to answer one of the most fundamental questions to address when studying a viral gene is whether the gene is essential to the viral life cycle in tissue culture as well as tropism for a specific cell type (Sweet et al., 2007; Benyesh-Melnick et al., 1975; Akel and Sweet, 1993).

The first targeted mutations in herpesviruses introducing deletion or disruption to genes of interest have been achieved by site-directed homologous recombination of plasmids with transfected viral DNA in tissue culture (Mocarski et al., 1980). However, this procedure is limited by the low frequency and specificity of recombination. Moreover, genes essential for a function in only a certain cell type in vitro, therefore determining tropism, have been identified by genome analysis of strains attenuated after propagation in specific cell lines (Hahn et al., 2004). This mutagenesis strategy accelerated analyses of gene function of HSV-1, but because the technique required thymidine kinase negative mammalian cells for repair of the mutated or deleted viral gene, it could be utilized only in studies on herpesviruses with a broad cell tropism. Furthermore, positive selection schemes utilizing a growth disadvantage to the recombinant virus have been shown to be suffering from limits in purification of a clonal population of mutant virus in that wild type virus is invariably present during the selection process. Although this problem can to some extent be overcome by the simultaneous incorporation of marker genes (e.g. lac $Z$ cassette, green or red fluorescent protein into the selection procedure), selection against wild type virus remained technically very difficult and laborious. A huge amount of knowledge about role and function of genes of herpesviruses has been generated by the strategy mentioned above. Many HSV-1 genes have been described and understanding of their specific role in the pathogenesis in vivo has been expanded. This approach still remains the most widely used to study viral gene function in alphaherpesviruses and its modification has been utilized in other herpesviruses (HCMV, VZV, and $\mathrm{EBV}$ ). Where HSV-1 is concerned, the roles of genes involved in mechanisms of virus entry into cells, virus induced cell fusion, virion envelopment, and egress e.g. glycoproteins D and $\mathrm{B}(\mathrm{gD}$ and $\mathrm{gB})$, the heterodimer $\mathrm{gH}-\mathrm{gL}$ - all essential for replication in cultured cells as well as $\mathrm{gK}$ are identified by this strategy (Chouljenko et al., 2012; Melancon et al., 2005). The genes involved in the mechanism of HSV-1 at- 
tachment (gC and $\mathrm{gB}$ ) and spreading from cell-to-cell (gE/ gI complex) that remains largely unknown are also studied on del or null mutants (Ramachandran et al., 2008; Mingo et al., 2012). Furthermore, there are still many questions to be answered about the molecular mechanisms underlying the establishment and maintenance of herpesvirus latency and the reactivation of the virus from a latent state. Tight regulation of genes expressed during HSV-1 latency (latency associated transcript) and involved in latency establishment and maintenance is studied with the help of mutant viruses somehow deleted within the latency associated transcript region (Bertke et al., 2009). Similarly, mutants with deletion in sequence coding for ICP0 initiating lytic gene expression during latency are utilized in studies on features of latencyreactivation cycle characteristic for herpesviruses (Everett et al., 2004).

Another successful approach for mutational analysis of herpesvirus genes was the development of infectious clone technologies. Initial efforts to improve the efficiency for herpesvirus genomic manipulation involved the use of $E s$ cherichia coli plasmid replicons known as cosmids. As these cosmid clones can only accommodate up to $45 \mathrm{kbp}$ of foreign DNA, a series of vectors that cover the entire herpesvirus genome in overlapping segments were required to facilitate the generation of recombinant viruses. Co-transfection of the set of cosmids into permissive cells of choice was followed by homologous recombination between overlapping gene segments of herpesviral genome resulting in the production of infectious virus particles. The phenotype of the virus progeny carrying mutations in genes of interest (nonessential for replication in vitro) can then be characterized by standard techniques of bacterial genetics. Specific mutations, insertions or deletions can be introduced into targeted genes and after transfection into cells and a generally homogeneous population of recombinant virus is generated. Typically, modifications were made to one fragment, followed by the rescue of infectious virus by introducing the complementing cosmids into cells to generate infectious virus. The main advantage of this technique is an absence of any requirement for selection against wild type virus and any foreign DNA (since no selectable markers are needed), which means that isolating minor population from a vast excess of wild type virus is eliminated. This approach has been successfully used to generate recombinant HSV-1, VZV, murine cytomegalovirus, and EBV (Ehsami et al., 2000; van Zijl et al., 1988; Tomkinson et al., 1993; Cohen et al., 1993). This approach appears to have represented a key step in the development of herpesviruses as biological vectors. Although the cosmid approach to generation of recombinant herpesviruses has proved to be powerful e.g. in use of cosmid libraries of cytomegaloviruses, it has limitations in the presence of unwanted adventitious mutations arising during many recombination events required for generation of full-length viral genome ( 6 for HSV-1 and 9 for HCMV) following transfection (Kemble et al., 1996). A limited number of unique restriction sites suitable for generating targeted insertions, deletions, or substitutions to cloned viral fragments against a cosmid background is another disadvantage of this technique.

Taken together, while all previous studies were successful, determining of function of viral genes was limited mainly by dependence on homologous recombination in virussusceptible cells and by difficulties in efficiently generating mutant viruses with altered or deleted genes essential for virus replication. These types of mutations required the codelivery of functional copies of the deleted genes to permit virus replication by using stably transformed cell lines that constitutively expressed the gene of interest or by using helper viruses. Limitations of methods for the generation of herpesvirus mutants mentioned above have largely been overcome by the development of techniques to maintain full-length viral genomes stably in E. coli.

\section{Studies on gene functions via application BAC system to herpesvirus genomes}

A breakthrough in study on herpesvirus genomes provided methodology for cloning large fragments of DNA based on the E. coli fertility factor or F plasmid firstly described by Shizuya et al. (1992). The F plasmid is present as a circular supercoiled extrachromosomal single binary copy plasmid in the bacterial host, and importantly for the study of herpesvirus genomes, is capable of stable maintenance of large DNA fragments up to $600 \mathrm{kbp}$ in length from complex genomic sources, which is sufficient to enable the genomes of all known herpesviruses.

This cloning system, referred to as a bacterial artificial chromosome (or BAC) system allows the complete construction of a mutant herpesvirus genome in a controlled manner prior to the reconstitution of infectious progeny (Messerle et al., 1997; Brune et al., 2000; Adler et al., 2003). A simple, random approach to identifying essential genes was the transposon-mediated mutagenesis of herpesviral genomes encoded in BACs, whereby transposon insertion sites were mapped by direct sequencing and the viability or non-viability of virus progeny was determined from the mutated genomes by reconstitution in tissue culture (Brune et al., 1999, 2000; Yu et al., 2003; Hobom et al., 2000; Smith and Enquist, 1999). Although originally utilized in order to generate a library of the human genome and a variety of plant genomes, BAC have proved extremely valuable for cloning and analysis of full-length viral genomes. In contrast to earlier methods, the generation of BAC mutants is a much quicker process. However, mutations affecting essential viral genes still require the gene product to be provided in 
trans to generate infectious virions. While this approach was very successful for the identification of some essential genes (Ménard et al., 2003; Brune et al., 2001), complete analysis to identify a full repertoire of essential genes (at least for certain cell types in vitro) has to be done gene by gene (Dunn et al., 2003). However, the great advantage of $\mathrm{BAC}$ mutagenesis in vitro lies in rapid identification of gene function and expression at unprecedented rates.

The development of BACs has revolutionized molecular cloning of large DNA molecules and they are now widely used in many applications, including investigation into herpesvirus biology. Messerle et al. (1997) extended this technique to the herpesvirus family by cloning the complete genome of murine cytomegalovirus into a BAC. Since this initial study, the genomes of at least 27 herpesviruses of human and veterinary importance and their derivatives have been used to create infectious clones using BAC technologies (icBAC) reviewed by Tischer and Kaufer (2012) including HSV-1 (Saeki et al., 1998), VZV (Yoshii et al., 2007), HCMV (Borst et al., 1999), and KSHV (Zhou et al., 2002). BACs with genomes of human herpesviruses are summarized in Table 1. This method is currently used in a large number of studies on essential as well as nonessential herpesviral genes (Brune et al., 1999, 2000; Adler et al., 2003; Yu et al., 2003). The principal advantage of BACs is the stability of insert propagation over multiple generations. Easy manipulation of the BAC constructs within the $E$. coli host has rapidly led to the preference for BACs over traditional cloning systems (O'Connor et al., 1989; Shizuya et al., 1992; Monaco et al., 1994; Delecluse et al., 1998; Borst et al., 1999). Protocols for cloning of viral genomes as BACs are now widely published.

Besides many animal herpesviruses (Table 2), murid herpesvirus 4 (murine gammaherpesvirus strain 68 (MHV68)) used as a model to study human gammaherpesvirus pathogenesis was cloned into BAC (Adler et al., 2000) and successfully used to determine the function of some genes as mentioned below. More recently, BAC technology has also been extended to other DNA viruses including poxviruses (Wang and Osterrieder, 2011; Domi and Moss, 2002;
Cottingham et al., 2008; Roth et al., 2011), and to RNA viruses including coronaviruses and flaviviruses, through the development of infectious cDNA clones (Almazán et al., 2000; Yun et al., 2003).

In addition to BAC, two other vectors- yeast origin (YAC) and mammalian artificial chromosome capable of maintaining very large DNA inserts of up to $1 \mathrm{Mbp}$ are used to clone large foreign genomic DNA. Since the latter have numerous disadvantages, including instability, chimaerism and handling difficulties such as shearing of DNA (Monaco and Larin, 1994), BACs are undoubtedly the system of choice for studying herpesviruses. The essential property is in the context of herpesvirus biology, as the genomes of many of these viruses contain a variety of repetitive sequence elements that could promote instability. However, many studies done for the past three decades have successfully propagated icBAC over multiple passages with high fidelity without detecting rearrangements, thus can be utilized in genome sequencing, identification of the causative genetics of disease and the development of disease models. Furthermore, a BAC clone can help progress the effects of in vitro passage of virus isolates. The mechanism of attenuation of the virulence of a herpesvirus usually achieved by repeated passage in susceptible cells (Churchill et al., 1969; Osborn and Walker, 1971; Takahashi et al., 1974) via apparent accumulation of mutations, for example in the development of an attenuated strain for use as a vaccine, can be followed with the help of icBAC. Alternatively, BACs can support rapid characterization of viral genes through random transposon mutagenesis. This is particularly useful in initial studies into newly isolated, little studied viruses (Estep et al., 2007) where full genomic sequence data is still unknown.

Isolated cloned herpesviral genes can be used to study the function in non-infected cells, for example as is done for the protein localization of a library of HSV-1, HSV-2, HCMV, and EBV genes shown by Salsman et al. (2008). Nevertheless, analysis of protein functions and localization in the context of the infection is indispensable, and mutation and tagging of the target gene has to be done in the viral genome.

Table 1. Summary of the human herpesvirus genomes which have successfully been cloned to date as bacterial artificial chromosomes (BACs) in E. coli

\begin{tabular}{|c|c|c|c|c|c|c|}
\hline Subfamily & Formal name & Acronym & Common name & Acronym & $\begin{array}{c}\text { Genome size } \\
(\mathrm{kbp})\end{array}$ & Year published \\
\hline \multirow{2}{*}{$a$} & Human herpesvirus 1 & HHV-1 & Herpes simplex virus 1 & HSV-1 & 152 & 1998 \\
\hline & Human herpesvirus 1 & HHV-2 & Herpes simplex virus 2 & HSV-2 & 155 & 2004 \\
\hline \multirow{2}{*}{$B$} & Human herpesvirus 3 & $\mathrm{HHV}-3$ & Varicella-zoster virus & $\mathrm{VZV}$ & 172 & 1998 \\
\hline & Human cytomegalovirus 5 & HHV-5 & & HCMV & 229 & 1999 \\
\hline \multirow{3}{*}{$\gamma$} & Human herpesvirus 6 & & & HHV-6 & 159 & 2009 \\
\hline & Human herpesvirus 4 & HHV-4 & Epstein-Barr virus & EBV & 172 & 2002 \\
\hline & Human herpesvirus 8 & HHV-8 & $\begin{array}{l}\text { Kaposi's sarcoma-associa- } \\
\text { ted virus }\end{array}$ & KSHV & 137 & 2007 \\
\hline
\end{tabular}


Table 2. Summary of the animal herpesvirus genomes which have successfully been cloned to date as bacterial artificial chromosomes (BACs) in E. coli

\begin{tabular}{|c|c|c|c|c|c|}
\hline Subfamily & Formal name & Acronym & Common name & $\begin{array}{c}\text { Genome size } \\
(\mathrm{kbp})\end{array}$ & Year published \\
\hline \multirow[t]{10}{*}{$\alpha$} & Suid herpesvirus 1 & SuHV1 & Pseudorabies virus & 143 & 1999 \\
\hline & Gallid herpesvirus 2 & GaHV2 & Marek's disease virus type 1 & 178 & 2000 \\
\hline & Bovine herpesvirus 1 & BoHV1 & Infectious bovine rhinotracheitis virus & 135 & 2002 \\
\hline & Equid herpesvirus 1 & EHV1 & Equine abortion virus & 150 & 2002 \\
\hline & Canid herpesvirus 1 & CaHV1 & Canine herpesvirus & 160 & 2006 \\
\hline & Meleagrid herpesvirus 1 & HVT & Herpesvirus of turkey & 160 & 2006 \\
\hline & Gallid herpesvirus 3 & GaHV3 & Marek's disease virus type 2 & 164 & 2009 \\
\hline & Equid herpesvirus 4 & EHV4 & Equine rhinopneumonitis virus & 146 & 2006 \\
\hline & Felid herpesvirus 1 & FeHV1 & Feline rhinotracheitis virus & 136 & 2010 \\
\hline & Cercopithecine herpesvirus 9 & SVV & Simian varicella virus & 125 & 2011 \\
\hline \multirow[t]{3}{*}{ B } & Murid herpesvirus 1 & MuHV1 & Mouse cytomegalovirus & 230 & 1997 \\
\hline & Caviid herpesvirus 2 & CavHV2 & Guinea pig cytomegalovirus & 233 & 2001 \\
\hline & Macacine herpesvirus 3 & McHV3 & Rhesus cytomegalovirus & 221 & 2003 \\
\hline \multirow[t]{6}{*}{$\gamma$} & Murid herpesvirus 4 & MuHV4 & Murine herpesvirus 68 & 119 & 2000 \\
\hline & Saimiriine herpesvirus 2 & SaHV2 & Herpesvirus saimiri & 113 & 2003 \\
\hline & Bovine herpesvirus 4 & BoHV4 & Movar virus & 109 & 2005 \\
\hline & Alcelaphine herpesvirus1 & AlHV1 & Malignant catarrhal fever virus & 131 & 2006 \\
\hline & Macacine herpesvirus 5 & RRV & Rhesus rhadinovirus & 133 & 2007 \\
\hline & Macacine herpesvirus 4 & rhLCV & Rhesus lymphocryptovirus & 171 & 2011 \\
\hline
\end{tabular}

The principles of reverse genetics might offer manifold approaches to analysis of mutations which abolish localization or binding to partners and therefore can give further hints to its function in a pathway.

BACs are currently widely used in transgenic and knock out studies and are being used to monitor gene expression and target specific tissues in vivo. Due to the diverse applications for BACs, they will continue to be a cornerstone of virological research.

\section{Elucidating gammaherpesvirus biology with the help of studying mutants of murine gammaherpesviruses}

The subfamily Gammaherpesvirinae contains a large scale of herpesviruses infecting mammals including two human herpesviruses EBV and KSHV associated with lymphomas and nasopharyngeal carcinoma (Rickinson and Kieff, 2001) as well as lymphoproliferative disorders and Kaposi's sarcoma (Schulz, 1998). These viruses are limited in study by restricted host range and an absence of an appropriate animal model (Davison et al., 2009; Kúdelová and Rajčáni, 2009). Hence, murine gammaherpesvirus infection of mice serves as probably the most amenable animal model for studying the pathogenesis of human lymphoproliferative disorders caused by gammaherpesviruses. From five murine gammaherpesvirus isolates recovered from small free-living rodents Cletrionomys glareolus (MHV-60, MHV-68, and MHV-72) and Apodemus flavicollis (MHV-76 and MHV-78) (Blaškovič et al., 1980) and further three (MHV-Šumava, MHV-4556, and MHV-5682) isolated later (Kožuch et al., 1993), MHV-68 was first the genome sequence of which was fully identified (Virgin et al., 1997). Based on DNA sequence homology, its 63 genes were found homologous to herpesvirus saimiri and KSHV and many of them to EBV. In 2000, it was classified as Murid herpesvirus 4 (MHV-4) strain 68 (synonyms mouse herpesvirus strain 68 and murine gammaherpesvirus 68 (MHV-68)) into a new species, Murid herpesvirus 4, the genus Rhadinovirus, the subfamily Gammaherpesvirinae (van Regenmortel et al., 2000). To date, MHV-68 is the most studied murine gammaherpesvirus (Speck and Virgin, 1999; Virgin and Speck 1999; Rajčáni and Kúdelová, 2007). Pilot studies using laboratory mice inoculated by intranasal route, showed that MHV-68 spreads to the lungs, where it replicates in alveolar cells as well as vascular endothelial cells. From the lungs, the virus spreads via the bloodstream to spleen and bone marrow and to the mediastinal lymph nodes via lymphatics (Rajčáni et al., 1985). An IM-like syndrome (similar to EBV) may develop during acute infection, when primed T/CD8 lymphocytes eliminate the B cells expressing non-structural early viral proteins (Blackman et al., 2000). Similar to other gammaherpesviruses, MHV-68 establishes long-term latency in B lymphocytes (spleen, lymph nodes), macrophages, dendritic cells but also in lung endothelial cells (Stewart et al., 1998, Sunil-Chandra et al., 1992, 1993). Lymphoproliferative disease and solid tumors (lymphomas) were described in Balb/c mice infected with MHV-68 as well as other strains (Flaño et al., 2002; Mistríková and Rajčáni, 
2008). A chronic leukemia-like syndrome associated with spleen enlargement and extremely a high number of peripheral blood leukocytes was also noted.

Genome of MHV-68 contains a unique sequence of $118,237 \mathrm{bp}$ that is flanked by multiple copies of a 1,213 bp terminal repeat (Virgin et al., 1997). To date, a full sequence of MHV-76 has been identified (Macrae et al., 2001). Partial sequencing of the ends of MHV-Šumava genome revealed at the left end a $\sim 9.3 \mathrm{kbp}$ deletion similar to that in MHV-76 but also an $\sim 1.5 \mathrm{kbp}$ deletion present at the right end not found in other murine gammaherpesviruses (Blaškovičová et al., 2007). Furthermore, partial sequencing of about one fifth of genome of MHV-72 and MHV-4556 determined divergence in some genes from MHV-68 (Halásová et al., 2011; Kúdelová et al., 2012). According to sequence homology of MHV-68 coded polypeptides to other herpesviruses, most of them have homologs in all herpesvirus subfamilies but a lot of them only within members of the gammaherpesvirus subfamily. At least 16 proteins are murine gammaherpesvirus specific (designed as $\mathrm{M}$ genes) most likely having roles important in virus relation to a specific host.

A key study to determine genes of MHV-68 essential in vitro growth was done by the Song group in 2005 with the help of signature-tagged mutagenesis (Song et al., 2005). Besides previously described essential genes common in all subfamilies of herpesviruses, (Table 3) they identified two genes with unknown function (ORF33, ORF42) and such genes homologous only to $\beta$ - and $\gamma$-subfamily (ORF31, ORF32, ORF34, ORF53, ORF55, ORF66) or only to $\gamma$ - subfamily (ORF35, ORF52). Moreover, several genes nonessential with unknown function were determined (ORF10, ORF11, ORF18, ORF23, ORF27, ORF58) which have homologs mostly only in $\gamma$-subfamily.

These findings aroused great interest in MHV-68 and huge work has been done elucidating the function of its genes in the past last two decades. MHV-68 genes common with other herpesviruses but also those identified as unique are studied by traditional methods as well as BAC technology to answer to the most recent issues related to gammaherpesvirus pathogenesis concerning mechanisms of latency, reactivation from latency and tumorigenesis. MHV-68 genes transcribed during latency and reactivation as ORF73/LANA (a homologue to KSHV coded LANA1) and ORF50 (KSHV/ Rta homologue) as well as genes coding cell genes homologs (M11/bcl-2, ORF72/v-Cyclin and ORF74/v-GPCR) serve as useful models for better understanding of their homologs in important human gammaherpesviruses. For example, ORF73.STOP mutant grew well in vitro and induced an acute phase of infection in vivo. In the lungs of mice, the stop mutant exhibited a delayed replication and a severe defect in the establishment of latency in splenocytes (Moorman et al., 2003; Forrest et al., 2007). To investigate the function of vCyclin encoded by ORF72, a recombinant vCyclin.Lac.Z de-
Table 3. MHV-68 ORFs coding for essential in vitro growth proteins and their homologs in herpesvirus subfamilies

\begin{tabular}{|c|c|c|}
\hline Name & Function (localization) & $\begin{array}{l}\text { Common in } \\
\text { subfamilies }\end{array}$ \\
\hline ORF 6 & ssDNA binding protein & $\alpha, \beta, \gamma$ \\
\hline ORF 7 & Transport protein & $\alpha, \beta, \gamma$ \\
\hline ORF 8 & Glycoprotein B, (virion) & $\alpha, \beta, \gamma$ \\
\hline ORF 9 & DNA polymerase & $\alpha, \beta, \gamma$ \\
\hline ORF 17 & Capsid protein & $\alpha, \beta, \gamma$ \\
\hline ORF 19 & Tegument protein & $\alpha, \beta, \gamma$ \\
\hline ORF 19 & Tegument protein & $\alpha, \beta, \gamma$ \\
\hline ORF 22 & Glycoprotein H, (virion) & $\alpha, \beta, \gamma$ \\
\hline ORF 24 & HCMV UL87-like, (virion) & $\beta, \gamma$ \\
\hline ORF 25 & Major capsid protein, (virion) & $\alpha, \beta, \gamma$ \\
\hline ORF 26 & Capsid protein, triplex-2, (virion) & $\alpha, \beta, \gamma$ \\
\hline ORF 29b & Packaging protein, (virion) & $\alpha, \beta, \gamma$ \\
\hline ORF 29a & Packaging protein, (virion) & $\alpha, \beta, \gamma$ \\
\hline ORF 39 & Glycoprotein M & $\alpha, \beta, \gamma$ \\
\hline ORF 40 & Helicase-primase & $\gamma$ \\
\hline ORF 43 & Capsid protein & $\alpha, \beta, \gamma$ \\
\hline ORF 44 & Helicase-primase & $\alpha, \beta, \gamma$ \\
\hline ORF 45 & $\begin{array}{l}\text { IRF-7 binding protein homologue, } \\
\text { (virion) }\end{array}$ & $\gamma$ \\
\hline ORF 48 & (virion) & $\gamma$ \\
\hline ORF 50 & Transcriptional activator & $\gamma$ \\
\hline ORF 56 & Helicase-primase & $\alpha, \beta, \gamma$ \\
\hline ORF 57 & Posttranscriptional regulator & $\alpha, \beta, \gamma$ \\
\hline ORF 62 & $\begin{array}{l}\text { Assembly, DNA maturation, tri- } \\
\text { plex-1, capsid protein, (virion) }\end{array}$ & $\gamma$ \\
\hline ORF 63 & Tegument protein & $\gamma$ \\
\hline ORF 64 & Tegument protein & $\alpha, \beta, \gamma$ \\
\hline M9 (ORF 65) & Small capsid protein, (virion) & $\gamma$ \\
\hline ORF 67 & Tegument protein & $\beta, \gamma$ \\
\hline ORF 68 & Glycoprotein & $\alpha, \beta, \gamma$ \\
\hline ORF $75 c$ & Tegument protein/ FGARAT, (virion) & $\gamma$ \\
\hline
\end{tabular}

letion/insertion construct was constructed and mutant was significantly compromised in capacity to reactivate from latency (van Dyk et al., 1999, 2000). The MHV-68 ORF74/ vGPCR was reported to induce the transformed phenotype in transfected 3T3 cells comparable to that of LMP-1, the known EBV oncogene. The splenocytes of mice infected with the ORF74del MuHV-4 mutant showed significantly reduced reactivation from latency (Lee et al., 2003).

The properties of some proteins encoded by MHV-68 draw attention due to hopes that they are explored for vaccination or in gene therapy of immunological and lymphoproliferative diseases. For example, the use of viral chemokine-binding protein M3 protein, a pan-chemokine antagonist, in experimental animal model to overcome cellular inflammatory responses induced by recombinant oncolytic vesicular stomatitis virus in hepatocellular carci- 
noma lesions resulted in prolonged therapeutical effect and animal survival with a $50 \%$ cure rate (Wu et al., 2008). Subsequently, such proteins are studied using expression vectors suitable for the preparation of protein in bulk in mammalian, insect or E. coli cells. To clarify broad chemokine binding activities of M3 protein, baculovirus and pET expression system was used (Alexander et al. 2002; Pančík et al., 2013). Furthermore, recombinant lentivirus expressing ORF20 helped to describe the ability of protein encoded to induce arrest in the G2/M phase of cell-cycle, followed by apoptosis (Nascimento and Parkhouse, 2007). Recombinant MHV-68, carrying a cassette for the expression of heterologous proteins (e.g. the non-structural protein NS3 of Hepatitis C virus (MHV-68-NS3), are also used to address the question of whether the insertion of a defined foreign sequence interferes with the biological properties of the recombinant virus in vivo, to analyze the underlying mechanism, and whether MHV-68 could be potentially used as a gene delivery vector (El-Gogo et al., 2008).

Thus, study on a relatively novel gammaherpesvirus - MHV-68 could serve as an example of simultaneous applications of the traditional and the most modern approaches to elucidating herpesvirus biology. Earlier studies introduced stop codons, antibiotic resistance sequences (mostly tetracycline and kanamycin), LacZ cassette, or $\beta$-galactoside gene to interrupt the gene of interest e.g. M1-M3 genes (Clambey et al., 2000; Jacoby et al., 2002; Herskowitz et al., 2005; van Berkel et al., 2002), gp150 gene (Stewart et al., 2004), M11 gene (Gangappa et al., 2002), ORF20 (Nascimento et al., 2011), ORF26-28 (May et al., 2005a,b), ORF50 (May et al., 2004; Pavlova et al., 2003), ORF72 (Hoge et al., 2000; van Dyk et al., 2000). Later on, cloning into BAC was preferred as in the case of K3 (Stevenson et al., 2002), ORF11 (Boname et al., 2005), ORF18 (Arumugaswami et al., 2006), ORF24 (Wong et al., 2007), ORF31 (Jia et al., 2004), ORF33 (Guo et al., 2009), ORF45 (Jia et al., 2005), ORF52 (Bortz et al., 2007) and many others.

In conclusion, it seems that the combination of both approaches at least for some genes may advance identification of their roles and functions in vitro and in vivo.

\section{Conclusions}

Herpesviruses are medically important pathogens for humans and animals. Various individual properties of herpesviruses, cell tropism, different forms of maintenance of their genome in hosts and different effects on the cell cycle can be assigned using a wide range of recent and desired applications of BAC technology to forward reverse genetics. Herpesviruses have a large genome size, with numerous nonessential genes which make herpesviruses attractive for gene therapy, as nonessential genes can be substituted with therapeutic genes. Since the analysis of nonessential genes for replication is still dependent on the construction of complementing cell lines, an increase in knowledge of the gene functions of herpesviruses can be expected in the offing, thus promising new possibilities in the use of herpesviruses in gene therapy and vaccine development (Meseda et al., 2004).

Acknowledgement. This work was supported by the joint grant agency of Slovak Ministry of Education and Slovak Academy of Sciences VEGA (\#2/0091/13 and \#2/0134/11).

\section{References}

Adler H, Messerle M, Wagner M, Koszinowski UH, J. Virol. 74, 6964-6974, 2000. http://dx.doi.org/10.1128/ IVI.74.15.6964-6974.2000

Adler H, Messerle M, Koszinowski UH, Rev. Med. Virol. 13, 111121, 2003. http://dx.doi.org/10.1002/rmv.380

Akel HM, Sweet C, FEMS Microbiol. Lett. 113, 253-260, 1993. http://dx.doi.org/10.1111/j.1574-6968.1993.tb06523.x

Alcami A, Koszinowski UH, Immunol. Today. 21, 447-455, 2000. http://dx.doi.org/10.1016/S0167-5699(00)01699-6

Alexander JM, Nelson CA, van Berkel V, Lau EK, Studts JM, Brett TJ, Speck SH, Handel TM, Virgin HW, Fremont DH, Cell 111, 343-356, 2002. http://dx.doi.org/10.1016/S00928674(02)01007-3

Almazán F, González JM, Pénzes Z, Izeta A, Calvo E, Plana-Durán J, Enjuanes L, Proc. Natl. Acad. Sci. USA 97, 5516-5521, 2000. http://dx.doi.org/10.1073/pnas.97.10.5516

Andoniou CE, Degli-Esposti MA, Immunol. Cell Biol. 1, 99-106, 2006. http://dx.doi.org/10.1111/j.14401711.2005.01412.x

Arumugaswami V, Wu TT, Martinez-Guzman D, Jia Q, Deng H, Reyes N, Sun R, J. Virol. 80, 9730-9340, 2006. http:// dx.doi.org/10.1128/JVI.00246-06

Benyesh-Melnick M, Schaffer PA, Courtney RJ, Esparza J, Kimura S, Cold Spring Harb. Symp. Quant. Biol. 39, 731-746, 1975. http://dx.doi.org/10.1101/SQB.1974.039.01.086

Bertke AS, Patel A, Imai Y, Apakupakul K, Margolis TP, Krause PR, J. Virol. 83, 10007-10015. doi: 10.1128/JVI.00559-09, 2009. http://dx.doi.org/10.1128/JVI.00559-09

Blackman MA, Fla-o E, Usherwood E, Woodland DL, Mol. Med. Today. 6, 488-490, 2000. http://dx.doi.org/10.1016/S1357$\underline{4310(00) 01813-X}$

Blaškovič D, Stančeková M, Svobodová J, Mistríková J, Acta Virol. $24,468,1980$

Blaškovičová J, Tomášková J, Šupolíková M, Mistríková J, Kopáček J, Acta Virol. 51, 143-148, 2007. Boname JM, May JS, Stevenson PG, J. Virol. 79, 3163-3168, 2005. http://dx.doi. org/10.1128/JVI.79.5.3163-3168.2005

Borst EM, Hahn G, Koszinowski UH, Messerle M, J. Virol. 73, 8320-8329, 1999.

Bortz E, Wang L, Jia Q, Wu TT, Whitelegge JP, Deng H, Zhou ZH, Sun R, J. Virol. 81, 10137-10150, 2007. http://dx.doi. org/10.1128/JVI.01233-06 
Böttcher S, Klupp BG, Granzow H, Fuchs W, Michael K, Mettenleiter TC, J. Virol. 80, 9910-9915, 2006. http://dx.doi. org/10.1128/JVI.01247-06

Brune W, Ménard C, Hobom U, Odenbreit S, Messerle M, Koszinowski UH, Nat. Biotechnol. 17, 360-364, 1999. http:// dx.doi.org/10.1038/7914

Brune W, Messerle M, Koszinowski UH, Trends Genet. 16, 254-259, 2000. http://dx.doi.org/10.1016/S0168-9525(00)020151

Brune W, Ménard C, Heesemann J, Koszinowski UH, Science 291, 303-305, 2001. http://dx.doi.org/10.1126/science.291.5502.303

Cohen JI, Seidel KE, Proc. Natl. Acad. Sci. USA 90, 7376-7380, 1993. http://dx.doi.org/10.1073/pnas.90.15.7376

Clambey ET, Virgin HW 4th, Speck SH, J. Virol. 74, 1973-1984, 2000. http://dx.doi.org/10.1128/JVI.74.4.1973-1984.2000

Cottingham MG, Andersen RF, Spencer AJ, Saurya S, Furze J, Hill AV, Gilbert SC, PLoS One. 3(2), e1638.

Corey L, J. Infect. Dis. 186, 29-33, 2002. http://dx.doi. org/10.1086/342971

Davison AJ, Vet. Microbiol. 1-2, 69-88, 2002. http://dx.doi. org/10.1016/S0378-1135(01)00492-8

Davison AJ, Eberle R, Ehlers B, Hayward GS, McGeoch DJ, Minson AC, Pellett PE, Roizman B, Studdert MJ, Thiry E, Arch. Virol. 154, 171-177. http://dx.doi.org/10.1007/s00705008-0278-4

Delecluse HJ, Hilsendegen T, Pich D, Zeidler R, Hammerschmidt W, Proc. Natl. Acad. Sci. USA 95, 8245-8250, 1998. http:// dx.doi.org/10.1073/pnas.95.14.8245

Dolan A, Jamieson FE, Cunningham Ch, Barnett BC, McGeoch DJ, J. Virol. 72, 2010-2021, 1998. Domi A, Moss B, Proc. Natl. Acad. Sci. USA 99, 12415-12420, 2002.http://dx.doi. org/10.1073/pnas.192420599

Dunn W, Chou C, Li H, Hai R, Patterson D, Stolc V, Zhu H, Liu F, Proc. Natl. Acad. Sci. USA 100, 14223-14228, 2003. http:// dx.doi.org/10.1073/pnas.2334032100

Ehsani ME, Abraha TW, Netherland-Snell C, Mueller N, Taylor MM, Holwerda B, J. Virol. 74, 8972-8979, 2000. http:// dx.doi.org/10.1128/JVI.74.19.8972-8979.2000

El-Gogo S, Flach B, Staib C, Sutter G, Adler H, Virology 380, 322327. http://dx.doi.org/10.1016/j.virol.2008.07.034

Estep RD, Powers MF, Yen BK, Li H, Wong SW, J. Virol. 81, 29572969, 2007. http://dx.doi.org/10.1128/JVI.01997-06

Everett RD, Boutell C, Orr A, J. Virol. 78, 1763-1774, 2004. http:// dx.doi.org/10.1128/JVI.78.4.1763-1774.2004

Fla-o E, Woodland DL, Blackman MA, Immunol. Res. 25, 201-217, 2002. http://dx.doi.org/10.1385/IR:25:3:201

Forrest JC, Paden CR, Allen RD 3rd, Collins J, Speck SH, J. Virol. 81, 11957-11971, 2007 http://dx.doi.org/10.1128/ JVI.00111-07

Fu M, Deng R, Wang J, Wang X, Acta Virol. 52, 31-40, 2008.

Gangappa S, van Dyk LF, Jewett TJ, Speck SH, Virgin HW 4th, J. Exp. Med. 195, 931-940, 2002. http://dx.doi.org/10.1084/ jem.20011825

Guo H, Wang L, Peng L, Zhou ZH, Deng H, J. Virol. 83, 1058210595, 2009. http://dx.doi.org/10.1128/JVI.00497-09

Hahn G, Revello MG, Patrone M, Percivalle E, Campanini G, Sarasini A, Wagner M, Gallina A, Milanesi G, Koszinowski U,
Baldanti F, Gerna G, J. Virol. 78(18), 10023-10033, 2004. http://dx.doi.org/10.1128/JVI.78.18.10023-10033.2004

Halásová Z, Valovičová M, Mačáková K, Pančík P, Belvončíková $\mathrm{P}$, Režuchová I, Kúdelová M, Acta Virol. 55, 317-325, 2011. http://dx.doi.org/10.4149/av 201104317

Hemling N, Röyttä M, Rinne J, Pöllänen P, Broberg E, Tapio V, Vahlberg T, Hukkanen V, Ann. Neurol. 54, 267-271, 2003. http://dx.doi.org/10.1002/ana.10662

Herskowitz JH, Jacoby MA, Speck SH, J. Virol. 79, 2261-2273, 2005. http://dx.doi.org/10.1128/JVI.79.4.2261-2273.2005

Hobom U, Brune W, Messerle M, Hahn G, Koszinowski UH, J. Virol. 74, 7720-7729, 2000. http://dx.doi.org/10.1128/ JVI.74.17.7720-7729.2000

Hoge AT, Hendrickson SB, Burns WH, J. Virol. 74, 7016-7023, 2000. http://dx.doi.org/10.1128/JVI.74.15.7016-7023.2000

Holzerlandt R, Orengo C, Kellam P, Albà MM, Genome Res. 12, 1739-1748, 2002. http://dx.doi.org/10.1101/gr.334302

Champier G, Hantz S, Couvreux A, Stuppfler S, Mazeron MC, Bouaziz S, Denis F, Alain S, Antivir. Ther. 12, 217-232, 2007.

Chouljenko DV, Kim IJ, Chouljenko VN, Subramanian R, Walker JD, Kousoulas KG, J. Virol. 86, 4262-4270. http://dx.doi. org/10.1128/JVI.06766-11

Churchill AE, Chubb RC, Baxendale W, J. Gen. Virol. 4, 557-564, 1969. http://dx.doi.org/10.1099/0022-1317-4-4-557

Jacoby MA, Virgin HW 4th, Speck SH, J. Virol. 76, 1790-1801, 2002. http://dx.doi.org/10.1128/JVI.76.4.1790-1801.2002

Jia Q, Wu TT, Liao HI, Chernishof V, Sun R, J. Virol. 78, 66106620, 2004. http://dx.doi.org/10.1128/JVI.78.12.6610$\underline{6620.2004}$

Jia Q, Chernishof V, Bortz E, Mchardy I, Wu TT, Liao HI, Sun R, J. Virol. 79, 5129-5141, 2005. http://dx.doi.org/10.1128/ JVI.79.8.5129-5141.2005

Kemble G, Duke G, Winter R, Spaete R, J. Virol. 70, 2044-2048, 1996.

Kožuch O, Reichel M, Leššo J, Remeňová A, Labuda M, Lysý J, Mistríková J, Acta Virol. 37, 101-105, 1993.

Kúdelová M; Rajčáni J (2009): In Gluckman TR (Ed.): Herpesviridae: Viral Structure, Life Cycle, and Infections. Book Series: Virology Research Progress, Nova Science Publishers Inc., USA, Chapt. 8, pp. 187-226.

Kúdelová M, Rajčáni J (2013): In Singh SK, Ruzek D (Eds): Neuroviral Infections. CRC Press LLC, Boca Raton, Florida, Chapt 7, pp. 169-214. http://dx.doi.org/10.1201/b13907-10

Kúdelová M, Halásová Z, Belvončíková $\mathrm{P}$, Pančík $\mathrm{P}$, Režuchová I, Valovičová M, Acta Virol. 56, 177-186, 2012. http://dx.doi. org/10.4149/av $2012 \quad 03 \quad 177$

Lee BJ, Koszinowski UH, Sarawar SR, Adler H, J. Immunol. 170, 243-251, 2003.

Liesegang TJ, Cornea. 20, 1-13, 2001. http://dx.doi. org/10.1097/00003226-200101000-00001

Mancuso R, Delbue S, Borghi E, Pagani E, Calvo MG, Caputo D, Granieri E, Ferrante P, J. Med. Virol. 79, 192-199, 2007. http://dx.doi.org/10.1002/jmv.20777

Matis J, Kúdelová M, Acta Virol. 45, 269-277, 2001.

Matis J, Kúdelová M (2005): In Robinson JW (Ed.): Frontiers in Protein Research. Nova Science Publishers Inc., New York, Chapt 3, pp. 65-85. 
May JS, Coleman HM, Smillie B, Efstathiou S, Stevenson PG, J. Gen. Virol. 85, 137-146, 2004. http://dx.doi.org/10.1099/ vir.0.19599-0

May JS, Walker J, Colaco S, Stevenson PG, J. Virol. 79, 50595068, 2005a. http://dx.doi.org/10.1128/JVI.79.8.5059$\underline{5068.2005}$

May JS, Coleman HM, Boname JM, Stevenson PG, J. Gen. Virol. 86, 919-928, 2005b. http://dx.doi.org/10.1099/vir.0.80661-0

McGeoch DJ, Dalrymple MA, Davison AJ, Dolan A, Frame MC, McNab D, Perry LJ, Scott JE, Taylor P, J. Gen. Virol. 69, 1531-1574, 1988. http://dx.doi.org/10.1099/0022-131769-7-1531

McGeoch DJ, Rixon FJ, Davison AJ, Virus Res. 117, 90-104, 2006. http://dx.doi.org/10.1016/j.virusres.2006.01.002

Melancon JM, Luna RE, Foster TP, Kousoulas KG, J. Virol. 79, 299-313, 2005. http://dx.doi.org/10.1128/JVI.79.1.299$\underline{313.2005}$

Ménard C, Wagner M, Ruzsics Z, Holak K, Brune W, Campbell AE, Koszinowski UH, J. Virol. 77, 5557-5570, 2003. http:// dx.doi.org/10.1128/JVI.77.10.5557-5570.2003

Meseda CA, Schmeisser F, Pedersen R, Woerner A, Weir JP, Virology. 318, 420-428, 2004. http://dx.doi.org/10.1016/j. virol.2003.09.033

Messerle M, Crnkovic I, Hammerschmidt W, Ziegler H, Koszinowski UH, Proc. Natl. Acad. Sci. USA 94, 14759-14763, 1997. http://dx.doi.org/10.1073/pnas.94.26.14759

Mingo RM, Han J, Newcomb WW, Brown JC, J. Virol. 86, 70847097. http://dx.doi.org/10.1128/JVI.00463-12

Mistríková J, Rajčáni J, Cent. Eur. J. Biol. 3, 19-30, 2008. http:// dx.doi.org/10.2478/s11535-008-0002-0

Mocarski ES, Post LE, Roizman B, Cell 22, 243-255, 1980. http:// dx.doi.org/10.1016/0092-8674(80)90172-5

Mocarski ES Jr, Kemble GW, Intervirology 39, 320-330, 1996.

Monaco AP, Larin Z, Trends Biotechnol. 12, 280-286, 1994. http:// dx.doi.org/10.1016/0167-7799(94)90140-6

Moorman NJ, Willer DO, Speck SH, J. Virol. 77, 10295-10303, 2003. http://dx.doi.org/10.1128/JVI.77.19.10295-10303.2003

Mori I, Nishiyama Y, Rev. Med. Virol. 15, 393-406, 2005. http:// dx.doi.org/10.1002/rmv.478

Nascimento R, Parkhouse RM, J. Gen. Virol. 88, 1446-1453, 2007. http://dx.doi.org/10.1099/vir.0.82589-0

Nascimento R, Costa H, Dias JD, Parkhouse RM, Arch. Virol. 156, 375-386. http://dx.doi.org/10.1007/s00705-010-0862-2

Nishiyama Y, Nagoya J. Med. Sci. 59, 107-119, 1996.

O'Connor M, Peifer M, Bender W, Science 244, 1307-1312, 1989. http://dx.doi.org/10.1126/science.2660262

Osborn JE, Walker DL, Infect. Immun. 3, 228-236, 1971.

Pančík P, Bauerová V, Kúdelová M, Acta Virol. 57, 59-68, 2013.

Pavlova IV, Virgin HW 4th, Speck SH, J. Virol. 77, 5731-5739, 2003. http://dx.doi.org/10.1128/JVI.77.10.5731-5739.2003

Post LE, Roizman B, Cell 25, 227-232, 1981. http://dx.doi. org/10.1016/0092-8674(81)90247-6

Rajčáni J, Blaškovič D, Svobodová J, Čiampor F, Hučková D, Staneková D, Acta Virol. 29, 51-60, 1985.

Rajčáni J, Kúdelová M (2007): In Minarovits J, Gonczol E, ValyiNagy T (Eds): Latency Strategies of Herpesviruses. Springer Berlin Heidelberg, New York, Chapt. 5, pp. 102136. http://dx.doi.org/10.1007/978-0-387-34127-9 5
Ramachandran S, Knickelbein JE, Ferko C, Hendricks RL, Kinchington PR, Virology 378, 254-264. http://dx.doi. org/10.1016/j.virol.2008.05.034

Rickinson AB, Kieff E (2001): In Knipe DM, Howley PM, Griffin DE, Martin MA, Lamb RA, Roizman B, Straus SE (Eds): Fields-Virology. Lippincott Williams \& Wilkins, Philadelphia, pp. 2575-2627.

Roizman B, Baines J, Comp. Immunol. Microbiol. Infect. Dis. 14, 63-79, 1991. http://dx.doi.org/10.1016/01479571(91)90122-T

Roizman B, Sears AE (1996): In Fields BN, Knipe DM, Howley PM (Eds): Fundamental Virology. Lippincott-Raven, Philadelphia, pp. 1043-1107.

Roth SJ, Höper D, Beer M, Feineis S, Tischer BK, Osterrieder N, Vet. Res. 42(1), 3, 2011. http://dx.doi.org/10.1186/12979716-42-3

Saeki Y, Ichikawa T, Saeki A, Chiocca EA, Tobler K, Ackermann M, Breakefield XO, Fraefel C, Hum. Gene Ther. 9, 2787 27894, 1998. http://dx.doi.org/10.1089/hum.1998.9.18$\underline{2787}$

Salsman J, Zimmerman N, Chen T, Domagala M, Frappier L, PLoS Pathog. 4, e1000100. Shizuya H, Birren B, Kim UJ, Mancino V, Slepak T, Tachiiri Y, Simon M, Proc. Natl. Acad. Sci. USA 89, 8794-8797, 1992.

Schaffer PA, Curr. Top. Microbiol. Immunol. 70, 51-100, 1975. http://dx.doi.org/10.1007/978-3-642-66101-3 3

Schulz TF, J. Gen. Virol. 79, 1573-1591, 1998.

Simmons A, J. Infect. Dis. 186, 71-77, 2002. http://dx.doi. org/10.1086/342967

Smith GA, Enquist LW, J. Virol. 73, 6405-6414, 1999.

Song MJ, Hwang S, Wong WH, Wu TT, Lee S, Liao HI, Sun R, Proc. Natl. Acad. Sci. USA 102, 3805-3810, 2005. http://dx.doi. org/10.1073/pnas.0404521102

Speck SH, Virgin HW, Curr. Opin. Microbiol. 2, 403-409, 1999. http://dx.doi.org/10.1016/S1369-5274(99)80071-X

Stevenson PG, May JS, Smith XG, Marques S, Adler H, Koszinowski UH, Simas JP, Efstathiou S, Nat. Immunol. 3, 733-740, 2002.

Stewart JP, Usherwood EJ, Ross A, Dyson H, Nash, J. Exp. Med. 187, 1941-1951, 1998. http://dx.doi.org/10.1084/ jem.187.12.1941

Stewart JP, Silvia OJ, Atkin IM, Hughes DJ, Ebrahimi B, Adler H, J. Virol. 78, 10449-10459, 2004. http://dx.doi.org/10.1128/ JVI.78.19.10449-10459.2004

Sunil-Chandra NP, Efstathiou S, Nash AA, Virology. 193, 825-833, 1993. http://dx.doi.org/10.1006/viro.1993.1191

Sunil-Chandra NP, Arno J, Fazakerley J, Nash AA, Am. J. Pathol. 145, 818-826, 1994.

Sweet C, Ball K, Morley PJ, Guilfoyle K, Kirby M, J. Med. Virol. 79, 285-299, 2007. http://dx.doi.org/10.1002/jmv.20797

Takahashi M, Otsuka T, Okuno Y, Asano Y, Yazaki T, Lancet 2, 1288-1290, 1974. http://dx.doi.org/10.1016/S0140$\underline{6736(74) 90144-5}$

Tischer BK, Kaufer BB, J. Biomed. Biotechnol. 472537, 2012.

Tomkinson B, Robertson E, Yalamanchili R, Longnecker R, Kieff E, J. Virol. 67, 7298-7306, 1993.

van Berkel V, Barrett J, Tiffany HL, Fremont DH, Murphy PM, McFadden G, Speck SH, Virgin HW IV, J. Virol. 74, 6741- 
6747, 2000. http://dx.doi.org/10.1128/JVI.74.15.6741$\underline{6747.2000}$

van Dyk LF, Hess JL, Katz JD, Jacoby M, Speck SH, Virgin HW IV, J. Virol. 73, 5110-5122, 1999.

van Dyk LF, Virgin HW 4th, Speck SH, J. Virol. 74, 7451-7461, 2000. http://dx.doi.org/10.1128/JVI.74.16.7451-7461.2000

van Regenmortel MHV, Fauquet CM, Bishop DHL (2000): In Virus Taxonomy:Classification and Nomenclature of Viruses, 7th ICTV Report. Academic Press, San Diego, pp. 220-226.

van Zijl M, Quint W, Briaire J, de Rover T, Gielkens A, Berns A, J. Virol. 62, 2191-2195, 1988.

Virgin HW 4th, Latreille P, Wamsley P, Hallsworth K, Weck KE, Dal Canto AJ, Speck SH, J. Virol. 71, 5894-5904, 1997.

Virgin HW, Speck SH, Curr. Opin. Immunol. 11, 371-379, 1999. http://dx.doi.org/10.1016/S0952-7915(99)80063-6

Wang J, Osterrieder N, Virus Res. 159, 23-31, 2011. http://dx.doi. org/10.1016/j.virusres.2011.04.013
Wong E, Wu TT, Reyes N, Deng H, Sun R, J. Virol. 81, 6761-6764, 2007. http://dx.doi.org/10.1128/JVI.02726-06

Wozniak MA, Mee AP, Itzhaki RF, J. Pathol. 217, 131-138, 2009. http://dx.doi.org/10.1002/path.2449

Wu L, Huang TG, Meseck M, Altomonte J, Ebert O, Shinozaki K, García-Sastre A, Fallon J, Mandeli J, Woo SL, Hum. Gene Ther. 19, 635-647, 2008. http://dx.doi.org/10.1089/ hum.2007.163

Yoshii H, Somboonthum P, Takahashi M, Yamanishi K, Mori Y, Vaccine 25, 5006-5012, 2007. http://dx.doi.org/10.1016/j. vaccine.2007.04.064

Yu D, Silva MC, Shenk T, Proc. Natl. Acad. Sci. USA 100, 12396-12401, 2003. http://dx.doi.org/10.1073/pnas. 1635160100

Yun SI, Kim SY, Rice CM, Lee YM, J. Virol. 77, 6450-6465, 2003. http://dx.doi.org/10.1128/JVI.77.11.6450-6465.2003

Zhou FC, Zhang YJ, Deng JH, Wang XP, Pan HY, Hettler E, Gao SJ, J. Virol. 76, 6185-6196, 2002. http://dx.doi.org/10.1128/ JVI.76.12.6185-6196.2002 